\title{
Factors Mediating Alcohol Craving and Relapse: Stress, Compulsivity, and Genetics
}

\author{
Zachary A. Rodd, Kristin K Anstrom, Darin J. Knapp, Ildiko Racz, Andreas Zimmer, Salvatore \\ Serra, Richard L. Bell, Donald J. Woodward, George R. Breese, and Giancarlo Colombo \\ From the Institute of Psychiatric Research, Departments of Psychiatry, Indiana University School \\ of Medicine, Indianapolis, IN (ZAR RLB); Wake Forest University School of Medicine, Winston- \\ Salem, NC (KKA, DJW); North Carolina School of Medicine, Chapel Hill, NC (DJK GRB); University \\ of Bonn, Bonn, Germany (IR AZ); and C.N.R. Institute of Neuroscience, University of Cagliari, \\ Cagliari, Italy (SS GC).
}

\begin{abstract}
This article represents the proceedings of a symposium at the 2004 annual meeting of the International Society for Biomedical Research on Alcoholism in Heidelberg, Germany. The symposium was organized by Zachary A. Rodd and Giancarlo Colombo. The presentations were (1) Pharmacological reversal of cycled withdrawal-sensitized or stress-sensitized withdrawal anxiety and enhanced ethanol drinking, by Darin J. Knapp and George R. Breese, (2) Alcohol craving and relapse in rats genetically selected for high alcohol preference, by Zachary A. Rodd and Richard L. Bell, (3) Exposure to stress increases dopaminergic burst firing in awake rats, by Kristin Anstrom and Donald J. Woodward, (4) Involvement of cannabinoid CB1 and GABA $A_{B}$ receptors in the control of relapselike drinking in alcohol-preferring Sardinian alcohol-preferring rats by Giancarlo Colombo and Salvatore Serra, and (5) Stress-induced ethanol drinking in $\mathrm{CB}^{-/}{ }^{-}$, POMC, and PENK knockout mice, by Idiko Racz and Andreas Zimmer.
\end{abstract}

\section{Keywords}

Alcohol Relapse; Alcohol Withdrawal; Alcohol Reinforcement; Alcohol Pharmacotherapeutics

\begin{abstract}
Animal models are invaluable tools for elucidating the normal and abnormal functions of the human nervous system and behavior. The ability of any animal model to depict aspects of the complex processes that underlie human behavior is predicated on that model being a relevant analog of the human condition. A number of animal models, examining different facets of alcohol-related behaviors, have been constructed to study genetic and neurobiological factors underlying alcoholism and alcohol abuse.

In humans, relapse behavior is a ubiquitous problem for individuals "recovering" from alcoholism, since at least 60 to $80 \%$ of abstinent alcoholics will relapse during their lifetime (Barrick \& Connors, 2002; Chiauzzi, 1991; Jaffe, 2002; Weiss et al., 2001). Although a number of criteria for relapse have been put forth, (Chiauzzi, 1991), the primary criterion holds that a return to levels of ethanol consumption equal to or greater than that observed prior to "abstinence" constitutes a relapse. Because alcohol abuse has been difficult to model in
\end{abstract}

Copyright $@ 2005$ by the Research Society on Alcoholism.

Reprint requests: Dr. Zachary A. Rodd, Indiana University School of Medicine, Institute of Psychiatric Research, 791 Union Drive, Indianapolis, IN 46202-4887; zrodd@iupui.edu. 
nonhuman species, it is not surprising that there are a limited number of animal models purported to mimic relapse to high alcohol drinking behavior.

In rodents, recent research has indicated a number of progressions in the attempt to model alcoholism. Specifically, relapse drinking (binge-drinking) can be modeled in rodents through manipulations of access to ethanol, the alcohol-deprivation effect (ADE). The ADE is defined as a temporary increase in the ratio of alcohol/total fluid intake and voluntary intake of EtOH solutions over baseline drinking conditions when EtOH is reinstated after a period of alcohol deprivation (Sinclair and Senter, 1967). The ADE is a phenomenon that has been observed in rats (McKinzie et al., 1998; Rodd-Henricks et al., 2000a; Sinclair and Senter, 1967), mice (Salimov et al., 1993), monkeys (Kornet et al., 1990; Sinclair, 1971), and humans (Burish et al., 1981; Mello and Mendelson, 1972). Furthermore, recent experiments have examined the effects of exposure to repeated periods of alcohol abstinence or repeated alcohol withdrawals on alcohol drinking in rodents (Holter et al., 1998; Rodd-Henricks et al., 2002a, 2002b; Rodd et al., 2003).

Alcohol seeking, a presumed animal correlate to alcohol craving in humans, has been modeled in a number of paradigms. Drug-Induced Reinstatement is a procedure in which the ability of noncontingent priming injections of previously self-administered drugs to reinitiate lever responding after extinction training is tested (Gerber and Stretch, 1975; Stretch et al., 1971). Cue-Induced Reinstatement is an experimental paradigm that assesses the ability of environmental cues to reinitiate lever responding after extinction training (Ciccocioppo et al., 2002, 2004; Katner et al., 1999; Katner and Weiss, 1999). Pavlovian Spontaneous Recovery (PSR) is an experimental technique in which animals intrinsically reinstate responsecontingent behaviors for a previously obtainable reinforcer after extinction and a period of rest.

The intent of the symposium was to present recent findings examining various aspects of alcohol relapse drinking and craving-like behaviors in rodents. Each report examined a unique facet of alcoholism modeled through an animal system, with an attempt to gain understanding of the phenomenon and perhaps to elucidate potential pharmacotherapeutics for the treatment of alcoholism.

\section{PHARMACOLOGICAL REVERSAL OF CYCLED WITHDRAWAL-SENSITIZED OR STRESS-SENSITIZED WITHDRAWAL ANXIETY AND ENHANCED ETHANOL DRINKING}

\section{Darin J. Knapp and George R. Breese}

These investigations focused on conditions that may link stress, anxiety, and relapse based on the premise that alcoholism proceeds from phases of abusive drinking to eventual relapse more readily when cycles of stress and/or eth-anol intake were involved (Breese et al., 2004a, 2004b; Le et al., 2000; Rodd-Henricks et al., 2001; Sinha, 2001; Spanagel and Hölter, 1999; Weiss et al., 2001). Previously, evidence showed that three five-day cycles of exposure to an ethanol diet followed by two days of withdrawal persistently sensitized anxiety-like behavior in Sprague-Dawley rats observed in the social interaction and elevated-plus maze tests (Overstreet et al., 2002). Such an effect was not found after exposure to similar amounts of ethanol in a continuous fashion over the same period of time. This phenomenon was reminiscent of the repeated withdrawal-sensitization of seizures investigated previously (Ballenger and Post, 1978; Becker and Hale, 1993; McCown and Breese, 1990) and was mimicked or blocked by repeatedly exposing animals to selective pharmacological agents (Knapp et al., 2005; Overstreet et al., 2003, 2004). This sensitization was also mimicked by repeatedly stressing the animals before or during ethanol exposure, and this action was attenuated by pharmacologically pretreating the stress episodes (Breese et al., 2004a). Further, 
treating the withdrawals limited the ability of a future stress episode to elicit the sensitized anxiety-like response (Breese et al., in press).

Related data demonstrated that alcohol-preferring P rats had a lower threshold for elicitation of this sensitization and that relatively short-term (five-day) cycles of voluntary ethanol intake and withdrawal could also elicit an alcohol deprivation effect (ADE) in P rats ( 5 to $6 \mathrm{~g} / \mathrm{kg}$ per day versus $3.5 \mathrm{~g} / \mathrm{kg}$ per day in noncycled rats) (Breese et al., 2004a). This effect persisted over 24 to 48 hours and was not accompanied by a change in anxiety-like behavior. P rats that were exposed to restraint stress during the first and second deprivation/withdrawal periods exhibited a comparable early ( 24 to 48 hours) deprivation-induced increase in alcohol intake. However, the drinking persisted for more days in these stressed animals such that their drinking averaged approximately $8 \mathrm{~g} / \mathrm{kg}$ per day over the five-day comparison period. Furthermore, these stressed, ethanol-deprived $\mathrm{P}$ rats exhibited anxiety-like behavior in the social interaction test on withdrawal from the voluntary alcohol drinking after the third cycle. Thus, stress increased both voluntary drinking and withdrawal-induced anxietylike behavior in the P rats.

Furthermore, when multiple stress exposures (60-minute restraint) were substituted for ethanol withdrawal experiences in Sprague-Dawley or P rats, a sensitized anxiety-like behavioral response occurred after a future withdrawal, even though the animals had not had multiple withdrawals. This effect did not appear to be related to circulating levels of corticosterone, nor were there stress effects in non-ethanol exposed animals.

In pharmacological experiments, many agents with actions on the GABA/benzodiazepine, 5HT, or CRF (corticotropin-releasing factor) systems attenuated the development of the multiple withdrawal-sensitized response. For example, intraperitoneal administration of the nonpeptide CRF type-1 receptor antagonists CRA1000 (3 mg/kg) or CP-154,526 (10 mg/kg) or 5-HT $2 \mathrm{C}$ receptor inverse agonist SB243213 (3 mg/kg) or antagonist SB242084 (3 mg/kg) during early withdrawals blocked the sensitized anxietylike behavior that was assessed during a future untreated withdrawal (Overstreet et al., 2004). Actions of other agents such as acamprosate (300 mg/kg), flumazenil ( $5 \mathrm{mg} / \mathrm{kg})$, alphaxalone $(9 \mathrm{mg} / \mathrm{kg})$ diazepam $(1 \mathrm{mg} / \mathrm{kg})$ (Knapp et al., $2005)$, the $\mathrm{GABA}_{\mathrm{B}}$ receptor agonist baclofen $(2.5 \mathrm{mg} / \mathrm{kg})$, and the $5-\mathrm{HT}_{2 \mathrm{C}}$ receptor antagonist ritanserin $(3 \mathrm{mg} / \mathrm{kg})$ were also found to exert such effects, but the glutamate modulating agents lamotrigine $(30 \mathrm{mg} / \mathrm{kg})$, ifenprodil $(10 \mathrm{mg} / \mathrm{kg}), \mathrm{MK}-801(0.3 \mathrm{mg} / \mathrm{kg})$, the peripheral benzodiazepine receptor antagonist PK11195 $(10 \mathrm{mg} / \mathrm{kg})$, the relatively specific 5-HT $2 \mathrm{~A}$ receptor antagonist ketan-serin $(3 \mathrm{mg} / \mathrm{kg})$, and the $5-\mathrm{HT}_{1 \mathrm{~A}}$ receptor antagonist WAY 100635 $(3 \mathrm{mg} / \mathrm{kg})$ were not active.

Other data show that the anxiety-like behavior of ethanol withdrawal can be pharmacologically sensitized and that select sites in brain appear to be important to the actions of specific agents. For example, repeated treatments of the animals with the benzodiazepine receptor inverse agonist DMCM $(0.5 \mathrm{mg} / \mathrm{kg}$ IP or $0.3 \mu \mathrm{g} / 1 \mu \mathrm{l}$ intra-amygdalarly) during the two weeks before ethanol exposure worsened the withdrawal from a future relatively short-term chronic ethanol exposure. Similarly, administration of the 5- $\mathrm{HT}_{2 \mathrm{C}}$ receptor inverse agonist Ro600175 (0.3 mg/ $\mathrm{kg}$ ) or the peptide CRF exerted similar sensitizing effects. In other central administration studies, repeated infusions of buspirone into the raphe $(0.5 \mu \mathrm{g} / 0.5 \mu \mathrm{l})$ or the $5-\mathrm{HT}_{2 \mathrm{C}}$ receptor inverse agonist SB243213 (3 $\mu \mathrm{g} / \mathrm{side}, 1 \mu \mathrm{l})$ bilaterally into the amygdala were active, but reversing the treatments in the two regions was not. Intra-amygdala flumazenil ( $5 \mu \mathrm{g} / \mathrm{side}, 1$ $\mu \mathrm{l})$ had comparable prophylactic actions.

When given before restraint stress in Sprague-Dawley rats, CRA1000, flumazenil, and buspirone, blocked the interaction of stress and ethanol withdrawal on anxiety-like behavior (Breese et al., 2004a). Similarly, in P rats repeatedly stressed during deprivation periods after cycles of voluntarily ethanol drinking, intraperitoneal administration of the atypical neuroleptic olanzapine (5 mg/kg), flumazenil, CP154,526, and buspirone blocked the sensitized anxiety- 
like behavior, whereas naloxone ( $20 \mathrm{mg} / \mathrm{kg})$, Haldol $(0.5 \mathrm{mg} / \mathrm{kg})$, and SB242084 did not. Further, treating the withdrawal periods with intraperitoneal buspirone, flumazenil, or CP-154,526 prevented a future stress from eliciting a sensitized anxiety response in SpragueDawley rats. Finally, pharmacological treatment of the stresses revealed that flumazenil, CRA1000, CP154,526, buspirone, naloxone (20 mg/kg), SB242084, or olanzapine reduced the stress enhancement of the ADE without appearing to significantly modify the ADE itself.

These and other reports (Rodd-Henricks et al., 2001; Spanagel and Hölter, 1999; Weiss et al., 2001) highlight the importance of the cycling pattern of ethanol exposure in the severity of withdrawal-type symptoms and the contribution of concurrent stress, receptor subtype, and animal strain in the manifestation of multiple withdrawal effects and stress on anxiety-like behavior and voluntary ethanol intake. Based on the allostasis (Koob and Le Moal, 2001; Koob, 2003) and stress/kindling (Breese et al., 2004b) models of alcoholic progression, it would appear imperative to treat withdrawal as well as stress periods, regardless of the temporal relation of these two critical variables. Finally, the relatively wide range of pharmacologically relevant targets during these early phases of adaptation to repeated ethanol exposure and stress emphasizes the potential importance of treating subjects early and possibly with more than one agent.

\section{EXPOSURE TO STRESS INCREASES DOPAMINERGIC BURST FIRING IN AWAKE RATS}

\section{Kristin K. Anstrom and Donald J. Woodward}

Alterations in dopaminergic neurotransmission, particularly activity of ventral tegmental area dopamine neurons, have been implicated in reward-related behaviors, including alcohol seeking and ingestion. In anesthetized animals, dopaminergic neuronal activity patterns consist of a combination of tonic and phasic burst firing modes (Grace, 1991) hypothesized to be regulated by dissociable circuit mechanisms (West et al., 2003). Tonic, steady-state extracellular dopamine levels are extremely stable, subject to slow rises and declines, and can be measured by dialysis. Circuit mechanisms hypothesized to regulate tonic dopamine levels include glutamatergic stimulation of synaptic dopamine release (Grace, 1991; West et al., 2003; Zigmond et al., 1998) as well as GABAergic regulation of dopaminergic population responses, or the number of active dopamine neurons (Floresco et al., 2003). Both systemic alcohol and self-administered alcohol cause increases in tonic dopamine in the striatum (Weiss et al., 1993) and have been shown to increase firing rate of dopamine neurons in vitro (Brodie et al., 1999).

In comparison, burst activity in dopamine neurons, defined as transient rapid firing of dopamine cell bodies, produces an enhanced release of intrasynaptic dopamine as compared with regular firing at the same rate (Gonon, 1988; Wightman and Zimmerman, 1990), but whether or not burst firing contributes to changes in tonic dopamine levels is debatable (Floresco et al., 2003; Phillips and Wightman, 2004). Burst firing is dependent on afferent stimulation from areas such as the prefrontal cortex (Kitai et al., 1999), subthalamic nucleus (Lokwan et al., 1999), and the pedunculopontine nucleus (Floresco et al., 2003), and transient effluxes of extracellular dopamine release due to burst firing can be measured in afferent areas by techniques such as fast-scan electrovoltametry.

Electrophysiological studies in awake animals have shown that salient events critical to learning, reward processing, and attentional selection elicit transient burst activity in dopamine cell bodies (Freeman et al., 1985; Horvitz et al., 1997; Schultz et al., 1993). In anesthetized animals, there is evidence that exposure to psychoactive drugs increases impulse activity (Marinelli et al., 2003) and that higher levels of dopaminergic burst firing may predict higher 
initial levels of responding for cocaine (Marinelli et al., 2000). It is unclear, however, how phasic activity contributes to sustained firing patterns in awake animals, how behaviorally relevant conditions change sustained impulse activity levels on a real-time basis, and if levels of dopaminergic burst firing can predict alcohol-reinforced response patterns. Identification of real-time changes in dopaminergic firing patterns in relation to specific phases of alcoholseeking or alcohol-taking behavior would thus give insight in to large-scale circuit mechanisms underlying discrete phases of these behaviors.

Acute stress is known to precipitate relapse in alcoholics and can reinstate alcohol-seeking behavior in animal models of relapse (Le and Shaham, 2002). One of the physiological responses to acute stress is a slow, steady increase in extracellular dopamine in the striatum (Imperato et al., 1992; Keller et al., 1988) and the prefrontal cortex (Abercrombie et al., 1989; Morrow et al., 1999). Whether or not stress increases activity in dopaminergic neurons is unclear. Stress activates c-fos expression in the ventral tegmental area (Morrow et al., 2000; Redmond et al., 2002), but others have found that stress does not increase dopaminergic activity in awake cats (Strecker and Jacobs, 1985). Recent developments in multiunit recording techniques have allowed us to record chronic activity patterns in single dopaminergic neurons across sequential days. By determining if and how dopaminergic firing patterns change on a real-time basis in models of stress, we will be able to identify which circuits may modulate dopaminergic neurotransmission and contribute to chronic behavioral states leading to relapse.

\section{INVOLVEMENT OF CANNABINOID CB1 AND GABAB RECEPTORS IN THE CONTROL OF RELAPSE-LIKE DRINKING IN SARDINIAN ALCOHOL- PREFERRING RATS}

\section{Giancarlo Colombo and Salvatore Serra}

Accumulating lines of experimental evidence indicate that the prototypic $\mathrm{GABA}_{\mathrm{B}}$ receptor agonist, baclofen, reduces alcohol consumption under different experimental procedures (Colombo et al., 2004a). These data suggest that the $\mathrm{GABA}_{\mathrm{B}}$ receptor may be considered a novel player among the receptor systems controlling different aspects of alcohol drinking behavior, including alcohol consumption, alcohol relapse, and alcohol appetitive properties.

Recent studies have investigated the effect of baclofen on the so-called alcohol deprivation effect (ADE), i.e., the transient increase in alcohol intake that occurs in several animal species after a period of abstinence from alcohol. This phenomenon has been proposed to model the loss of control over alcohol and the episodes of alcohol relapse in human alcoholics (McBride et al., 2002). These experiments were conducted by using the Sardinian alcohol-preferring (sP) rats, one of the few rat lines selectively bred worldwide for high alcohol preference and consumption. Rats of the sP line appear to constitute a proper animal model for pharmacological investigations on ADE, since they have been found to display a pronounced ADE during the first hour of reaccess to alcohol after a period of deprivation from alcohol (Agabio et al., 2000; Serra et al., 2003); further, ADE in SP rats has been found to be reduced by naltrexone (this laboratory, unpublished results), a drug that has some efficacy in reducing the likelihood of relapses in alcoholics (Streeton and Whelan, 2001), providing evidence of the predictive value of this animal model for the human pathology.

The first experiment (Colombo et al., 2003) evaluated the effect of baclofen on ADE in sP rats offered a choice between water and a single alcohol concentration (i.e., the standard concentration of $10 \%, \mathrm{vol} / \mathrm{vol})$. Specifically, adult male sP rats were individually housed and offered alcohol and water under the standard, home cage two-bottle choice with unlimited access for eight consecutive weeks (consuming an average of approximately $6 \mathrm{~g} / \mathrm{kg}$ per day alcohol). Subsequently, rats were divided into two groups (matched for alcohol intake over the 
last seven days): One group was deprived of alcohol for 14 consecutive days, during which water was the sole fluid available (alcohol-deprived rats); the second group continued to have unlimited access to alcohol and water (alcohol-nondeprived rats). At the end of the deprivation phase, 30 minutes before lights-off, rats of both groups (alcohol-deprived and alcoholnondeprived) were further divided into four subgroups ( $n=7$ to 8 ) and acutely injected with 0 , $1,1.7$, and $3 \mathrm{mg} / \mathrm{kg}$ baclofen (intra-peritoneal). Alcohol was represented at lights-off, and its consumption was recorded 60 minutes later. Standard rat chow was available throughout the study.

Alcohol intake was higher, by approximately 50\%, in vehicle-treated, alcohol-deprived rats than in vehicle-treated, alcohol-nondeprived rats, indicative of the development of a marked ADE. This increase in alcohol intake was prevented by baclofen administration; indeed, at all doses, baclofen resulted in a virtually complete suppression of the extra intake of alcohol produced by alcohol deprivation. Importantly, no dose of baclofen affected water and food intake, leading us to exclude that the action on ADE was secondary to its muscle-relaxant and sedative effects. Accordingly, a complementary experiment found that the doses of baclofen that suppressed ADE did not affect any measure of horizontal and vertical motor activities in alcohol-consuming sP rats tested in an open-field arena.

Subsequently, this laboratory investigated the effect of baclofen on the development of ADE when $\mathrm{sP}$ rats had access to multiple alcohol concentrations. A previous study characterized the behavior of sP rats exposed to this procedure (Serra et al., 2003). In that study, rats were initially exposed, for eight consecutive weeks, to the choice of four bottles containing 10, 20, and 30\% (vol/vol) alcohol and water, respectively. Comparable amounts of alcohol (expressed in grams per kilogram of pure alcohol) were consumed daily from each bottle. After two weeks of alcohol deprivation, a robust ADE developed. Its magnitude (in terms of extra intake of alcohol) and duration were similar to those previously observed in sP rats given the single $10 \%$ alcohol solution. However, a clear shift in preference developed toward the two highest alcohol concentrations (20 and 30\%), with negligible intakes from the $10 \%$ alcohol solution. ADE can be considered as an increased demand for alcohol by the "deprived" subject; consistently with this view, in the above study, the increased demand for alcohol occurred through two mechanisms: 1) augmentation of the amount of alcohol consumed and 2) selection of the alcohol concentrations (20 and 30\%), which, because of a more rapid absorption of alcohol, would give faster psychopharmacological effects.

In the experiment testing baclofen, adult male sP rats were individually housed and offered alcohol (10, 20, and 30\%, vol/vol) and water under the four-bottle choice with unlimited access for eight consecutive weeks (consuming an average of approximately $6 \mathrm{~g} / \mathrm{kg}$ per day alcohol). Rats were then divided into two groups (matched for alcohol intake over the last seven days): One group was deprived of alcohol for 14 consecutive days, during which water was the sole fluid available (alcohol-deprived rats); the second group continued to have unlimited access to the three alcohol solutions and water throughout the study (alcohol-nondeprived rats). At the end of the deprivation phase, 30 minutes before lights-off, rats of both groups (alcoholdeprived and alcohol-nondeprived) were further divided into four subgroups ( $n=7$ to 8 in both experiments) and acutely treated with 0,1 , and $3 \mathrm{mg} / \mathrm{kg}$ baclofen i.p. Alcohol was represented at lights-off, and its consumption was recorded 60 minutes later. Standard rat chow was available throughout the study.

Alcohol intake (expressed as the sum of alcohol consumed from each of the three bottles) in vehicle-treated, alcohol-deprived rats was markedly higher than in vehicle-treated alcoholnondeprived rats, indicating the development of ADE also under this procedure. The magnitude of this increase in alcohol intake averaged approximately $50 \%$, being comparable to that 
previously observed under the single-concentration procedure. As expected, both doses of baclofen completely suppressed the extra amount of alcohol consumed after the deprivation.

When the data on alcohol intake from each bottle were analyzed, vehicle-treated, alcoholnondeprived rats resulted as having consumed comparable quantities of alcohol from each of the three alcohol solutions; in contrast, and in agreement with the initial observation (Serra et al., 2003), vehicle-treated alcohol-deprived rats displayed a clear preference $(>80 \%)$ for the $30 \%$ alcohol solution. Interestingly, injection of both 1 and $3 \mathrm{mg} / \mathrm{kg}$ baclofen completely abolished this shift in preference.

Taken together, the results of these experiments indicate that the acute administration of baclofen suppressed both the quantitative (amount of alcohol consumed) and qualitative (preference for the most concentrated solutions) aspects of the increased demand for alcohol associated with alcohol deprivation in $\mathrm{SP}$ rats. These results also suggest an involvement of the $\mathrm{GABA}_{\mathrm{B}}$ receptor in the neural substrate mediating $\mathrm{ADE}$ in $\mathrm{sP}$ rats.

Finally, because of the predictive validity of ADE as an experimental model of alcohol relapse, the results of the present study suggest that baclofen may prove to be of some efficacy in preventing relapses in human alcoholics. The results of preliminary, clinical surveys (Addolorato et al., 2002; Flannery et al., 2004) apparently support this hypothesis and suggest that baclofen may constitute a novel medication for alcoholism.

\section{STRESS-INDUCED ETHANOL DRINKING IN CB1-/-, POMC, AND PENK KNOCKOUT MICE}

\section{Ildiko Racz and Andreas Zimmer}

Stress is a part of our everyday life, and each of us responds to it in a different way. Some individuals excel under stress, whereas others suffer from it. Clearly, stress can contribute to the development of psychiatric disorders, including drug addiction. Indeed, there is a substantial body of evidence demonstrating that stressful environment or lifestyle increases the probability of alcohol misuse in humans and relapse in abstinent alcoholics (Brady and Sonne, 1999).

Recently, our laboratory and others have used genetic mouse models to study the role of neuromodulators in drug-related behaviors that are influenced by stress. The endocannabinoids are lipid signaling molecules that bind and activate the neuronal CB1 cannabinoid receptor. Pharmacological studies suggested that the behavioral effects of alcohol, including alcohol drinking and alcohol preference, are modulated through the endocannabinoid signaling system (Hungund and Basavarajappa, 2004). For example, chronic ethanol treatment increases the synthesis of endocannabinoids and downregulates brain CB1 receptors (Basavarajappa and Hungund, 2002). Blockade of the $\mathrm{CB}_{1}$ receptor with SR 141716A reduced ethanol consumption in rats and mice (Colombo et al., 2004b; Freedland et al., 2001).

We have studied the role of the endogenous cannabinoid system as a potential mediator of stress-related ethanol drinking in $\mathrm{CB} 1$ receptor mutant mice $\left(\mathrm{CB}^{--}\right)$. Acute behavioral responses to ethanol were not changed in the absence of $\mathrm{CB} 1$ receptors. Also, there was no difference in ethanol preference in a two-bottle choice model between wild-type and mutant animals under low stress conditions, although females displayed a higher preference for alcohol in both genotypes. When $\mathrm{CB} 1^{+/+}$animals were exposed to a mild foot shock stressor or to a swim stress, they showed a temporary increase in ethanol preference. A social stressor (exposure to an unfamiliar animal) led to a decreased ethanol preference. Most strikingly, none of these stressors had any effect on ethanol consumption in $\mathrm{CB}^{-/-}$animals, although other physiological stress responses (e.g., c-fos induction) were similar in $\mathrm{CB} 1^{-/-}$and $\mathrm{CB} 1^{+/+}$mice. 
We also evaluated somatic symptoms of ethanol withdrawal in animals when their access to ethanol was suddenly disrupted after several weeks of continuous ethanol consumption. Indeed, we observed strong withdrawal symptoms such increased anxiety, handling-induced convulsions, and hypermotility in $\mathrm{CB} 1^{+/+}$animals. $\mathrm{CB} 1^{-/-}$mice, in stark contrast, showed no somatic withdrawal symptoms. Together, these results clearly point to an important role of the endocannabinoid system in stress-induced alcohol consumption and in the manifestation of alcohol dependence.

The endogenous opioid system has also been implicated in the modulation of alcohol-induced behaviors and alcohol addiction (de Waele and Gianoulakis, 1993; Kiefer et al., 2002; Oswald and Wand, 2004; Patel and Pohorecky, 1989). In fact, the opioid receptor antagonist naloxone is already in clinical use for relapse prevention in abstinent alcoholics.

We therefore applied the same behavioral protocols to study ethanol drinking behavior in endorphin-deficient $\mathrm{POMC}^{-/-}$and enkephalin-deficient $\mathrm{PENK}^{-/-}$mice. Our preliminary results indicate that both strains have lower preference for alcohol compared with wild-type mice, thus supporting a function of these opioid peptides in ethanol reward. We also found evidence to suggest that the lack of endorphin affected the stress modulation of alcohol consumption. Surprisingly, the effect was different in the two sexes: We found a decrease in alcohol preference in males and a significant increase in females. Interestingly, sex differences in ethanol consumption after chronic stress were also found in humans (Richman et al., 2004).

Our findings clearly indicate that the endocannabinoid and opioid systems play important and distinct roles in the modulation of several aspects that have been implicated in alcohol drinking and addiction. A further evaluation of CB1 antagonists for the therapy of alcohol addiction, perhaps in a combination with other drugs acting on opioid receptors, seems warranted.

\section{ALCOHOL CRAVING AND RELAPSE IN RATS GENETICALLY SELECTED FOR HIGH ALCOHOL PREFERENCE}

\section{Zachary A. Rodd and Richard L. Bell}

Before the late 1980s, the majority of researchers considered extinction, the loss of instrumentally learned behavioral responses or the loss of a Pavlovian conditioned response, as "unlearning," or the destruction of old learning/memory (McClelland and Rumelhart, 1985, Rescorla and Wagner, 1972). Although this hypothesis may be intuitive, the past 20 years of research have indicated that extinction is not unlearning (Bouton, 1988, 2000, 2002, 2004; Bouton and Swartzentruber, 1991; Delemater, 2004; Falls, 1998; Rescorla, 2001). The current view of extinction is that it is not a process to destroy first-learned information but is a process of obtaining new learning (Bouton, 2002, 2004; Delemater, 2004; Rescorla, 2001). The results of numerous studies have indicated that after extinction training, both the firstlearned and second-learned signals are present and that the signal or action is ambiguous (Bouton, 2002, 2004; Rescorla, 2001). The ambiguous quality of the signal/action after extinction is defined by the context.

There are at least four learning phenomena indicating that extinction does not produce unlearning (Bouton, 2002). The most common example of the retention of first-learned signals is the drug-reinstatement of responding model. US-induced (unconditioned stimulus) reinstatement (recovery of a behavior that occurs after extinction training when the animal is noncontingently administered the US) has been used to examine seeking behaviors for various drugs of abuse (Katz and Higgins, 2003; Shaham et al., 2003). Extinction training in a novel context results in the renewal phenomenon [a recovery of extinguished behavior(s) when reintroduced into the original context]. Reacquisition (the fast, often rapid, recovery of 
responding when the CS (conditioned stimulus) is paired with the US again) indicates that the first-learned signals are maintained after extinction. Additionally, reacquisition testing has shown the presence of both first- and second-learned signals. In multiple experiments, the existence of second-learned signals is indicated, since discriminative stimuli paired with extinction training can reduce the rate of reacquisition (Bouton, 1988; Carlton et al., 1996; Hart et al., 1995; Rickers and Bouton, 1989). Extinction learning (second-learned) persists for an extremely long time, since cues associated with extinction training can alter reacquired operant responding for months after extinction (Brooks et al., 2001). The last phenomenon to indicate that extinction does not produce unlearning is spontaneous recovery (Pavlovian spontaneous recovery, PSR).

PSR is defined as a recovery of responding, in the absence of the previously trained reward, which is observed after a period of rest after extinction (Domjan and Burkard, 1982; Macintosh, 1977). Conceptually, PSR is a unique phenomenon in that it is time-dependent. Although this may intuitively lead to the assumption that PSR responding is the product of "forgetting about extinction," research has indicated that this is not the case. The majority of researchers hold that PSR occurs because there is a temporal context to extinction training. Specifically, as time increases between extinction training, there is a shift in the ambiguity framework between firstand second-learned signals (Bouton, 1988; Estes, 1955; Spear, 1978). This stance is supported by research that has shown that retrieval cues for both first- and second-learned signals can alter PSR responding (Brooks, 2000; Brooks and Bouton, 1993; Brooks et al., 1999). Thus, the PSR phenomenon can be viewed as a shift from expressing second-learned signals to firstlearned signals without an elimination of either learning. The expression of a PSR is directly correlated to reward saliency (Macintosh, 1977; Robbins, 1990), contextual cues associated with first-learned signals, and the amount of first- and second-learned associations (Brooks, 2000). In general, the PSR phenomenon has been asserted to be the result of a intrinsic shift away from the recent extinction (second-) learning to the initial reinforced learning responses, which reflects an intrinsic motivation to obtain the previously administered reward (Bouton, 2002, 2004; Rescorla, 2001). Therefore, the PSR model may represent a unique paradigm to study craving-like behaviors.

The first experiment from our laboratory examining the PSR phenomenon was used to determine the long-term effects of periadolescent EtOH drinking in alcohol-preferring $(\mathrm{P})$ rats on alcohol seeking in adulthood (Rodd-Henricks et al., 2002a, 2002b). Briefly, P rats were given 30 days of access to $15 \% \mathrm{EtOH}$ and water or water only during periadolescence (postnatal days 30 to 60) or adulthood (greater than postnatal day 110) followed by two weeks of water only for both groups. The results indicated that periadolescent alcohol consumption increased the rate of acquisition of oral operant self-administration, decreased the rate of extinction, and increased alcohol-seeking behaviors (PSR). In contrast, 30 days of alcohol consumption during adulthood did not alter responding during any test conditions. Compared with the periadolescent alcohol-naive group, periadolescent EtOH drinking enhanced the expression of an EtOH PSR in P rats (Rodd-Henricks et al., 2002a). Additionally, priming amounts of EtOH (Rodd-Henricks et al., 2002a) or the presence of an EtOH odor (Rodd-Henricks et al., 2002b) increased the expression of a PSR, but these effects were greater in Prats that consumed EtOH during periadolescence. In humans, adolescent alcohol drinking may have enduring consequences, as suggested by the association of early onset of alcohol and drug abuse with increased risk for later drug-related problems, including alcoholism (Anthony and Petronis, 1995; Chou and Pickering, 1992).

Recently, we conducted a preliminary study to examine the effects of repeated alcohol deprivation on extinction responding and expression of PSR in adult P male rats. Briefly, $\mathrm{P}$ rats were allowed to respond for $15 \% \mathrm{EtOH}$ and water on a concurrent FR5-FR1 schedule of reinforcement for six weeks; they were randomly assigned to one of four groups ( $n=6 /$ group). 
The groups were never deprived (two groups), once deprived, or repeatedly deprived (four deprivations). The two nondeprived groups consisted of a group that was maintained on an FR5 schedule of reinforcement for EtOH, and a group that had the response requirement increase to an FR10. The total amount of operant chamber access to EtOH was held constant across all groups, so that the nondeprived animals were given 12 weeks and one day access to EtOH before undergoing seven consecutive extinction sessions. The once-deprived group received 12 weeks of daily access, two weeks of deprivation, and a single reexposure session before the seven consecutive extinction sessions. The repeatedly deprived group was given six weeks' access, two weeks of deprivation-two weeks of reexposure, for a total of four deprivation cycles (12 weeks of total EtOH access); after the fourth deprivation, the P rats were given one reexposure session before the seven consecutive extinction sessions. After extinction training, rats were given a two-week home cage period and then reintroduced into the operant environment in the absence of EtOH and water. During the one-session reinstatement, $\mathrm{P}$ rats in the deprived groups showed increased responding on the EtOH lever, which was further enhanced by repeated deprivations. A single deprivation slightly retarded extinguishing the responses on the EtOH lever during extinction training, whereas repeated deprivations had a profound effect on retarding extinction training. Additionally, nondeprived rats maintained at an FR5 schedule of reinforcement for EtOH responded more during the second extinction session than rats increased to an FR10. Thus, there was evidence for a negative contrast effect for EtOH extinction responding in $\mathrm{P}$ rats, and that elevated responding during extinction training is not dependent on experience with an elevated level of responding before extinction. Moreover, compared with the nondeprived and once-deprived groups, the rats that underwent multiple deprivations increased the magnitude and duration of responding during the PSR test sessions. The nondeprived groups (FR5 and FR10) displayed comparable levels of responding during the initial PSR test session (72 \pm 10 and $89 \pm 7$ ). Thus, high level of responding during PSR testing is not dependent on prior experience with a high level of responding during maintenance. Similarly, past research has indicated that repeat deprivations, or exposure to repeated alcohol withdrawals, increase the breakpoint ratio during progressive ratio testing (Coccocioppo et al., 2003; Rodd et al., 2003). These data sets indicate that the reward value is increased after deprivation. Overall, data from multiple research studies suggest that neuronal alterations are occurring as a result of repeated cycles of $\mathrm{EtOH}$ access and deprivation that increase measures of alcohol reinforcement and alcohol seeking. It would be important to understand the neurobiological mechanisms underlying these neuronal alterations and to develop strategies to counter these changes.

\section{SUMMARY}

Overall, the presentations reported recent findings examining alcohol relapse drinking and alcohol seeking. A general finding is that repeated exposure to periods of alcohol deprivations or withdrawal periods increase ethanol drinking and other alcohol behaviors. Additionally, exposure to stressors may facilitate alcohol relapse drinking or act to alter alcohol drinking similar to exposure to repeated alcohol deprivations or withdrawals. Furthermore, the presentations highlighted potential pharmacotherapeutics for the treatment of alcoholism while indicating some of the neurotransmitter systems involved in alcohol relapse drinking and alcohol-seeking (craving) behaviors.

\section{Acknowledgments}

These studies were supported in part by AA07611 (ZAR), AA12262 (ZAR), AA11605 (DJK), AA14284 (DJK), and AA14949 (DJK). 


\section{REFERENCES}

Abercrombie ED, Keefe KA, DiFrischia DS, Zigmond MJ. Differential effect of stress on in vivo dopamine release in striatum, nucleus accumbens, and medial frontal cortex. J Neurochem 1989;52:1655-1658. [PubMed: 2709017]

Addolorato G, Caputo F, Capristo E, Domenicali M, Bernardi M, Janiri L, Agabio R, Colombo G, Gessa GL, Gasbarrini G. Baclofen efficacy in reducing alcohol craving and intake: a preliminary doubleblind randomised controlled study. Alcohol Alcohol 2002;37:504-508. [PubMed: 12217947]

Agabio R, Carai MAM, Lobina C, Pani M, Reali R, Vacca G, Gessa GL, Colombo G. Development of short-lasting alcohol deprivation effect (ADE) in Sardinian alcohol-preferring rats. Alcohol 2000;21:59-62. [PubMed: 10946158]

Anthony JC, Pertonis KR. Early-onset drug use and risk of later drug problems. Drug Alcohol Depend 1995;40:9-15. [PubMed: 8746919]

Ballenger JC, Post RM. Kindling as a model for alcohol withdrawal syndromes. Br J Psychiatry 1978;133:1-14. [PubMed: 352467]

Barrick C, Connors GJ. Relapse prevention and maintaining abstinence in older adults with alcohol-use disorders. Drugs Aging 2002;19:583-594. [PubMed: 12207552]

Basavarajappa BS, Hungund BL. Neuromodulatory role of the endocannabinoid signaling system in alcoholism: an overview. Prosta-glandins Leukot Essent Fatty Acids 2002;66:287-299.

Becker HC, Hale RL. Repeated episodes of ethanol withdrawal potentiate the severity of subsequent withdrawal seizures: an animal model of alcohol withdrawal 'kindling.' . Alcohol Clin Exp Res 1993;17:94-98. [PubMed: 8452212]

Bouton ME. Context and ambiguity in the extinction of emotional learning: implications for exposure therapy. Behav Res Ther 1988;26:137-149. [PubMed: 3365204]

Bouton ME. A learning theory perspective on lapse relapse and the maintenance of behavior change. Health Psychol 2000;19:57-63. [PubMed: 10709948]

Bouton ME. Context, ambiguity, and unlearning: sources of relapse after behavioral extinction. Biol Psych 2002;52:976-986.

Bouton ME. Context and behavioral processes in extinction. Learn Mem 2004;11:485-494. [PubMed: 15466298]

Bouton ME, Swartzentruber D. Slow reacquisition following extinction: context encoding and retrieval mechanisms. J Exp Psychol Anim Behav Process 1989;15:43-53.

Brady KT, Sonne SC. The role of stress in alcohol use, alcoholism treatment, and relapse. Alcohol Res Health 1999;23:263-71. [PubMed: 10890823]

Breese GR, Knapp DJ, Overstreet DH. Stress sensitization of ethanol withdrawal-induced reduction in social interaction: inhibition by CRF-1 and benzodiazepine receptor antagonists and a 5-HT1Areceptor agonist. Neuropsychopharmacology 2004a;29:470-482. [PubMed: 12955093]

Breese GR, Overstreet DH, Knapp DJ. Conceptual framework for the etiology of alcoholism: a 'kindling'/ stress hypothesis. Psychopharmacology 2004b;178:367-380. [PubMed: 15765253]

Breese GR, Overstreet DH, Knapp DJ, Navarro M. Prior Multiple Ethanol Withdrawals Enhance StressInduced Anxiety-Like Behavior: Inhibition by CRF(1)- and Benzodiazepine-Receptor Antagonists and a 5-HT(1a)-Receptor Agonist. Neuropsychopharmacology. 20052005 Feb 23 [Epub ahead of print].

Brodie MS, Pesold C, Appel SB. Ethanol directly excites dopaminergic ventral tegmental area reward neurons. Alcohol Clin Exp Res 1999;23:1848-1852. [PubMed: 10591603]

Brooks DC. Recent and remote extinction cues reduce spontaneous recovery. Q J Exp Psychol 2000;153:25-58.

Brooks DC, Bouton ME. Retrieval cue for extinction attenuates spontaneous recovery. J Exp Psychol Anim Behav Process 1993;19:77-89. [PubMed: 8418218]

Brooks DC, Karamanlian BR, Foster VL. Extinction and spontaneous recovery of ataxic tolerance to ethanol in rats. Psychopharmacology 2001;153:491-496. [PubMed: 11243497]

Brooks DC, Palmatier HI, Garcia EO, Johnson JL. An extinction cue reduces spontaneous recovery of a conditioned taste aversion. Anim Learn Behav 1999;27:77-88. 
Burish TG, Maisto SA, Cooper AM, Sobell MB. Effects of voluntary short-term abstinence from alcohol on subsequent drinking patterns of college students. J Stud Alcohol 1981;42:1013-1020. [PubMed: 7334801]

Calton JL, Mitchell KG, Schachtman TR. Conditioned inhibition produced by extinction of a conditioned stimulus. Learn Motiv 1996;27:335-361. [PubMed: 8979936]

Chiauzzi, EJ. Preventing Relapse in the Addictions: A Biopsychosocial Approach. New York, NY: Pergamon Press; 1991.

Chou SP, Pickering RP. Early onset of drinking as a risk factor for lifetime alcohol-related problems. Brit J Addiction 1992;87:1199-1204.

Ciccocioppo R, Economidou D, Fedeli A, Angeletti S, Weiss F, Heilis M, Massi M. Attenuation of ethanol self-administration and of conditioned reinstatement of alcohol-seeking behaviour by the antiopioid peptide nociceptin/orphanin FQ in alcohol-preferring rats. Psycho-pharmacology 2004;172:170178.

Ciccocioppo R, Martin-Fardon R, Weiss F. Effect of selective blockade of $\mu 1$ or $\delta$ opioid receptor on reinstatement of alcohol-seeking behavior by drug-associated stimuli in rats. Neuropsychopharmacology 2002;27:391-399. [PubMed: 12225696]

Colombo G, Addolorato G, Agabio R, Carai MAM, Pibiri F, Serra S, Vacca G, Gessa GL. Role of $\mathrm{GABA}_{\mathrm{B}}$ receptor in alcohol dependence: reducing effect of baclofen on alcohol intake and alcohol motivational properties in rats and amelioration of alcohol withdrawal syndrome and alcohol craving in human alcoholics. Neurotox Res 2004a;6:403-414. [PubMed: 15545024]

Colombo G, Serra S, Brunetti G, Vacca G, Carai MAM, Gessa GL. Suppression by baclofen of alcohol deprivation effect in Sardinian alcohol-preferring (sP) rats. Drug Alcohol Depend 2003;70:105-108. [PubMed: 12681531]

Colombo G, Vacca G, Serra S, Carai MA, Gessa GL. Suppressing effect of the cannabinoid CB1 receptor antagonist, SR 141716, on alcohol's motivational properties in alcohol-preferring rats. Eur J Pharmacol 2004b;498:119-123. [PubMed: 15363985]

Delamater AR. Experimental extinction in Pavlovian conditioning: behavioural and neuroscience perspectives. Q J Exp Psychol B 2004;57:97-132. [PubMed: 15204112]

de Waele JP, Gianoulakis C. Effects of single and repeated exposures to ethanol on hypothalamic betaendorphin and CRH release by the C57BL/6 and DBA/2 strains of mice. Neuroendocrinology 1993;57:700-709. [PubMed: 8367033]

Domjan, M.; Burkhard, B. The Principles of Learning and Behavior. Monterey, CA: Brooks Cole Publishing Company; 1982.

Estes WK. Statistical theory of spontaneous recovery and regression. Psychol Rev 1955;62:145-154. [PubMed: 14371893]

Falls, WA. Extinction: a review of theory and the evidence suggesting that memories are not erased with nonreinforcement. In: O'Donohue, W., editor. Learning and Behavior Therapy. Boston, MA: Allyn and Bacon; 1998. p. 205-229.

Flannery BA, Garbutt JC, Cody MW, Renn W, Grace K, Osborne M, Crosby K, Morreale M, Trivette A. Baclofen for alcohol dependence: a preliminary open-label study. Alcohol Clin Exp Res 2004;28:1517-1523. [PubMed: 15597084]

Floresco SB, West AR, Ash B, Moore H, Grace AA. Afferent modulation of dopamine neuron firing differentially regulates tonic and phasic dopamine transmission. Nat Neurosci 2003;6:968-973. [PubMed: 12897785]

Freedland CS, Sharpe AL, Samson HH, Porrino LJ. Effects of SR141716A on ethanol and sucrose selfadministration. Alcohol Clin Exp Res 2001;25:277-282. [PubMed: 11236843]

Freeman AS, Meltzer LT, Bunney BS. Firing properties of substantia nigra dopaminergic neurons in freely moving rats. Life Sci 1985;36:1983-1994. [PubMed: 3990520]

Gerber GH, Stretch R. Drug-induced reinstatement of extinguished self-administration behavior in monkeys. Pharmacol Biochem Behav 1975;3:1055-1061. [PubMed: 817297]

Gonon FG. Nonlinear relationship between impulse flow and dopamine-released by rat midbrain dopaminergic neurons as studied by in vivo electrochemistry. Neuroscience 1988;24:19-28. [PubMed: 3368048] 
Grace AA. Phasic verus tonic dopamine release and the modulation of dopamine system responsitivity: a hypothesis for the etiology of schizophrenia. Neuroscience 1991;41:1-24. [PubMed: 1676137]

Hart JA, Bourne MJ, Schactman TR. Slow reacquisition of a conditioned taste aversion. Anim Learn Behav 1995;23:297-303.

Holter SM, Engelmann M, Kirschke C, Liebsch G, Landgrad R, Spanagel R. Long-term ethanol selfadministration with repeated ethanol deprivation episodes changes ethanol drinking pattern and increase anxiety-related behaviour during ethanol deprivation in rats. Behav Pharmacol 1998;9:4148. [PubMed: 9832947]

Horvitz JC, Stewart T, Jacobs BL. Burst activity of ventral tegmental dopamine neurons is elicited by sensory stimuli in the awake cat. Brain Res 1997;759:251-258. [PubMed: 9221945]

Hungund BL, Basavarajappa BS. Role of endocannabinoids and cannabinoid CB1 receptors in alcoholrelated behaviors. Ann N Y Acad Sci 2004;1025:515-527. [PubMed: 15542757]

Imperato A, Angelucci L, Casolini P, Zocchi A, Puglisi-Allegra S. Repeated stressful experiences differently affect limbic dopamine release during and following stress. Brain Res 1992;577:194-199. [PubMed: 1606494]

Jaffe JH, Cascell NG, Kumor KM, Sherer MA. Cocaine-induced cocaine craving. Psychopharmacology 1989;97:59-64. [PubMed: 2496428]

Katner SN, Magalong JG, Weiss F. Reinstatement of alcohol-seeking behavior by drug-associated discriminative stimuli after prolonged extinction in the rat. Neuropsychopharmacology 1999;20:471479. [PubMed: 10192827]

Katner SN, Weiss F. Ethanol-associated olfactory stimuli reinstate ethanol-seeking behavior after extinction and modify extracellular dopa-mine levels in the nucleus accumbens. Alcohol Clin Exp Res 1999;23:1751-1760. [PubMed: 10591591]

Katz JL, Higgins ST. The validity of the reinstatement model of craving and relapse to drug use. Psychopharmacology 2003;168:21-30. [PubMed: 12695875]

Keller RW, Stricker EM, Zigmond MJ. Environmental stimuli but not homeostatic challenges produce apparent increases in dopaminergic activity in the striatum: an analysis by in vivo voltametry. Brain Res 1988;279:159-170. [PubMed: 6640335]

Kiefer F, Horntrich, Jahn H, Wiedemann K. Is withdrawal-induced anxiety in alcoholism based on betaendorphin deficiency? Psychopharmacology 2002;162:433-437. [PubMed: 12172698]

Kitai ST, Shepard PD, Callaway JC, Scroggs R. Afferent modulation of dopamine neuron firing patterns. Curr Opin Neurobiol 1999;6:690-697. [PubMed: 10607649]

Knapp DJ, Overstreet DH, Breese GR. Modulation of ethanol withdrawal-induced anxiety-like behavior during later withdrawals by treatment of early withdrawals with benzodiazepine/GABA ligands. Alcohol Clin Exp Res 2005;4:553-563. [PubMed: 15834220]

Koob GF. Alcoholism: allostasis and beyond. Alcohol Clin Exp Res 2003;27:232-243. [PubMed: 12605072]

Koob GF, LeMoal M. Drug addiction, dysregulation of reward, and allostasis. Neuropsychopharmacology 2001;24:97-129. [PubMed: 11120394]

Kornet M, Goosen C, Van Ree JM. The effect of interrupted alcohol supply on spontaneous alcohol consumption by rhesus monkeys. Alcohol Alcohol 1990;4:407-412. [PubMed: 2222574]

Le A, Shaham Y. Neurobiology of relapse to alcohol in rats. Pharmacol Ther 2002;94:137-156. [PubMed: 12191599]

Le AD, Harding S, Juzytsch W, Watchus J, Shalev U, Shaham Y. The role of corticotrophin-releasing factor in stress-induced relapse to alcohol-seeking behavior in rats. Psychopharmacology (Berl) 2000;150:317-324. [PubMed: 10923760]

Lokwan SJ, Overton PG, Berry MS, Clark D. Stimulation of the pedunculopontine tegmental nucleus in the rat produces burst firing in A9 dopaminergic neurons. Neuroscience 1999;92:245-254. [PubMed: 10392847]

Macintosh, JJ. Stimulus control: attentional factors. In: Honig, WK.; Staddon, JER., editors. Handbook on Operant Behavior. Englewood Cliffs, NJ: Prentice-Hall; 1977. p. 162-241.

Marinelli M, Cooper DC, Baker LK, White FJ. Impulse activity of midbrain dopamine neurons modulates drug-seeking behavior. Psychopharmacology 2003;168:84-98. [PubMed: 12721782] 
Marinelli M, White FJ. Enhanced vulnerability to cocaine self-administration is associated with elevated impulse activity of midbrain dopamine neurons. J Neurosci 2000;20:8876-8885. [PubMed: 11102497]

McBride WJ, Le A-D, Noronha A. Central nervous system mechanisms in alcohol relapse. Alcohol Clin Exp Res 2002;26:280-286. [PubMed: 11964569]

McClelland JL, Rummelhart DE. Distributed memory and the representation of general and specific information. J Exp Psychol Gen 1985;114:159-188. [PubMed: 3159828]

McCown TJ, Breese GR. Multiple withdrawals from chronic ethanol 'kindles' inferior collicular seizure activity: evidence for kindling of seizures associated with alcoholism. Alcohol Clin Exp Res 1990;14:394-399. [PubMed: 2378423]

McKinzie DL, Nowak KL, Yorger L, McBride WJ, Murphy JM, Lumeng L, Li T-K. The alcohol deprivation effect in the alcohol-preferring P rat under free-drinking and operant access conditions. Alcohol Clin Exp Res 1998;22:1170-1176. [PubMed: 9726292]

Mello NK, Mendelson MD. Drinking patterns during work-contingent and noncontingent alcohol acquisition. Psychosom Med 1972;34:139-164. [PubMed: 5017102]

Morrow BA, Elsworth JD, Rasmusson AM, Roth RH. The role of mesoprefrontal dopamine neurons in the acquisition and expression of conditioned fear in the rat. Neuroscience 1999;92:553-564. [PubMed: 10408604]

Oswald LM, Wand GS. Opioids and alcoholism. Physiol Behav 2004;81:339-358. [PubMed: 15159175]

Overstreet DH, Knapp DJ, Breese GR. Accentuated decrease in social interaction in rats subjected to repeated ethanol withdrawals. Alcohol Colin Exp Res 2002;26:1259-1268.

Overstreet DH, Knapp DJ, Moy SS, Breese GR. A 5-HT 1 A agonist and a 5-HT 2 C antagonist reduce social interaction deficit induced by multiple ethanol withdrawals in rats. Psychopharmacology 2003;167:344-352. [PubMed: 12677355]

Overstreet DH, Knapp DJ, Breese GR. Modulation of multiple ethanol withdrawal-induced anxiety-like behavior by CRF and CRF-1 receptors. Pharmacol Biochem Behav 2004;88:405-413. [PubMed: 14751471]

Patel VA, Pohorecky LA. Acute and chronic ethanol treatment on beta-endorphin and catecholamine levels. Alcohol 1989;6:59-63. [PubMed: 2524202]

Phillips PE, Wightman RM. Extrasynaptic dopamine and phasic neuronal activity. Nat Neurosci Erratum in: Nature 2004;423:461.

Redmond AJ, Morrow BA, Elsworth JD, Roth RH. Selective activation of the A10, but not A9, dopamine neurons in the rat by the predator odor, 2,5-dihydro-2,4,5-trimethylthiazoline. Neurosci Lett 2002;328:209-212. [PubMed: 12147308]

Rescorla, RA. Experimental extinction. In: Mowrer, RR.; Klein, SB., editors. Handbook of Contemporary Learning Theories. Mahwah, NJ: Erlbaum; 2001. p. 119-154.

Rescorla, RA.; Wagner, AR. A theory of Pavlovian conditioning: variations in the effectiveness of reinforcement and nonreinforcement. In: Black, AH.; Phkasy, WK., editors. Classical Conditioning II: Current Research and Theory. New York, NY: Appleton-Century-Crofts; 1972.

Richman JA, Wislar JS, Flaherty JA, Fendrich M, Rospenda KM. Effects on alcohol use and anxiety of the September 11, 2001, attacks and chronic work stressors: a longitudinal cohort study. Am J Public Health 2004;94:2010-2015. [PubMed: 15514245]

Rickers ST, Bouton ME. Reacquisition following extinction in appetitive conditioning. Anim Learn Behav 1996;24:423-436.

Robbins SJ. Mechanisms underlying spontaneous recovery in au-thoshaping. J Exper Psychol Anim Behav Processes 1990;16:235-249.

Rodd ZA, Bell RL, Kuc KA, Murphy JM, Lumeng L, Li T-K, McBride WJ. Effects of repeated alcohol deprivations on operant ethanol self-administration by alcohol-preferring $(\mathrm{P})$ rats. Neuropsychopharmacology 2003;28:1614-1621. [PubMed: 12799615]

Rodd-Henricks ZA, Bell RL, Kuc KA, Murphy JM, McBride WJ, Lumeng L, Li T-K. Effects of concurrent access to multiple ethanol concentrations and repeated deprivations on alcohol intake of alcohol-preferring rats. Alcohol Clin Exp Res 2001;25:1140-1150. [PubMed: 11505045]

Rodd-Henricks ZA, Bell RL, Kuc KA, Murphy JM, McBride WJ, Lumeng L, Li TK. Effects of Ethanol Exposure on Subsequent Acquisition and Extinction of Ethanol Self-Administration and Expression 
of Alcohol-Seeking Behavior in Adult Alcohol-Preferring (P) Rats. I. Periadolescent Exposure Alcohol Clin Exp Res 2002a;26:1632-1641.

Rodd-Henricks ZA, Bell RL, Kuc KA, Murphy JM, McBride WJ, Lumeng L, Li TK. Effects of Ethanol Exposure on Subsequent Acquisition and Extinction of Ethanol Self-Administration and Expression of Alcohol-Seeking Behavior in Adult Alcohol-Preferring (P) Rats. II. Adult Exposure Alcohol Clin Exp Res 2002b;26:1642-1652.

Rodd-Henricks ZA, McKinzie DL, Shaikh SR, Murphy JM, McBride WJ, Lumeng L, Li TK. Alcohol deprivation effect is prolonged in the alcohol preferring $(\mathrm{P})$ rat after repeated deprivations. Alcohol Clin Exp Res 2000;24:8-16. [PubMed: 10656186]

Salimov R, Salimova NB, Klodt P, Maisky A. Interaction between alcohol deprivation and morphine withdrawal in mice. Drug Alcohol Depend 1993;24:59-66. [PubMed: 8174503]

Schultz W, Apicella P, Ljungberg. Responses of monkey dopamine neurons to reward and conditioned stimuli during successive steps of learning a delayed response task. J Neurosci 1993;13:900-913. [PubMed: 8441015]

Serra S, Brunetti G, Vacca G, Lobina C, Carai MAM, Gessa GL, Colombo G. Stable preference for high ethanol concentrations after alcohol deprivation in Sardinian alcohol-preferring (sP) rats. Alcohol 2003;29:101-108. [PubMed: 12782251]

Shaham Y, Shalev U, Lu L, de Wit H, Stewart J. The reinstatement model of drug relapse: history, methodology, and major findings. Psychopharmacology 2003;168:3-20. [PubMed: 12402102]

Sinclair JD. The alcohol-deprivation effect in monkeys. Psychonomic Science 1971;25:1-22.

Sinclair JD. The alcohol-deprivation effect in monkeys. psychonomic Science 1971;25:1-22.

Sinclair JD, Senter RJ. Increased preference for ethanol in rats following deprivation. Psychonomic Science 1967;8:11-12.

Sinha R. How does stress increase risk of drug abuse and relapse. Psychopharmacology 2001;158:343359. [PubMed: 11797055]

Spanagel R, Hölter SM. Long-term alcohol self-administration with repeated alcohol deprivation phases: an animal model of alcoholism? Alcohol Alcohol 1999;34:231-243. [PubMed: 10344783]

Spear, NE. The Processing of Memories: Forgetting and Retention. Hillsdale, NJ: Erlbaum; 1978.

Strecker RE, Jacobs BL. Substantia nigra dopaminergic unit activity in behaving cats: effect of arousal on spontaneous discharge and sensory evoked activity. Brain Res 1985;361:339-50. [PubMed: 4084803]

Streeton C, Whelan G. Naltrexone, a relapse prevention maintenance treatment of alcohol dependence: a meta-analysis of randomized controlled trials. Alcohol Alcohol 2001;36:544-552. [PubMed: 11704620]

Stretch R, Gerber GJ, Wood SM. Factors affecting behavior maintained by response-contingent intravenous infusions of amphetamine in squirrel monkeys. Can J Physiol Pharmacol 1971;49:581589. [PubMed: 4996710]

Weiss F, Ciccocioppo R, Parsons LH, Katner S, Liu X, Zorrilla EP, Valdez GR, Ben-Shahar O, Angeletti S, Richter RR. Compulsive drug-seeking behavior and relapse. Neuroadaptation, stress, and conditioning factors. Ann N Y Acad Sci 2001;937:1-26.

West AR, Floresco SB, Charara A, Rosenkranz JA, Grace AA. Electrophysiological interactions between striatal glutamatergic and do-paminergic systems. Ann N Y Acad Sci 2003;1003:53-74. [PubMed: 14684435]

Wightman RM, Zimmerman JB. Control of dopamine extracellular concentration in rat striatum by impulse flow and uptake. Brain Res Brain Res Rev 1990;15:135-44. [PubMed: 2282449]

Zigmond MJ, Castro SL, Keefe KA, Abercrombie ED, Sved AF. Role of excitatory amino acids in the regulation of dopamine synthesis and release in the neostriatum. Amino Acids 1998;14:57-62. [PubMed: 9871442] 